\title{
Multiple Disease Protection by Rhizobacteria that Induce Systemic Resistance-Reply
}

\author{
Ellis Hoffland, Peter A. H. M. Bakker, and L. C. van Loon
}

Department of Plant Ecology and Evolutionary Biology, Utrecht University, P.O. Box 800.84, 3508 TB Utrecht, the Netherlands. Accepted for publication 13 November 1996.

During the last few years, Kloepper and coworkers have presented impressive evidence that plant growth-promoting rhizobacteria (PGPR) can protect cucumber plants against fungal, bacterial, and viral diseases. After Wei et al. (14) described induction of systemic resistance of cucumber to Colletotrichum orbiculare by six strains of PGPR, it was repeatedly stated in abstracts of meetings and book chapters that PGPR strains with previously demonstrated induced systemic resistance (ISR) against $C$. orbiculare led to multiple-pathogen control. However, these strains were not specified, and the communications lacked the technical details necessary to judge whether ISR was the (sole) mechanism responsible. Only recently, two PGPR strains were described as inducing resistance against Fusarium wilt (7), angular leaf spot (8), and anthracnose (9), but the strains had different designations and were not among those used previously (14). Hence, we at first concluded that proof still needed to be provided that the same inducing bacterium could suppress diseases caused by different infectious agents through ISR. Our experiments were conducted before Liu et al. (9) provided details about the strains inducing ISR against $C$. orbiculare. Nevertheless, we now see that the same PGPR strains did indeed protect against a foliar fungus, a soilborne fungus, and a bacterium, and we admit that we overlooked these recent results when submitting our paper.

To conclude that the mechanism responsible for suppression is ISR requires that the disease suppression is shown to be plant mediated and that it extends to plant parts that are not in contact with the inducing agent. This was neatly demonstrated for one PGPR strain in plants protected against Fusarium wilt, because a bioluminescent derivative of strain 89B-27 applied to one part of a split root system did not move to the part inoculated with Fusarium oxysporum f. sp. cucumerinum (7). The other studies did not address this question in detail, although it was mentioned that bacteria inducing systemic resistance were not translocated and did not colonize challenged leaves $(6,8)$. We agree that this implies ISR involvement. However, application of PGPR by seed treatment or cotyledon injection does not exclude colonization of the foliar parts of plants by the bacteria, and hence, microbial antagonism also might play a role. In our studies on ISR in carnation (11), radish (3), and Arabidopsis (10), we have repeatedly shown that inducing bacteria were not recoverable from sites where plants were challenged and that the spatial separation was maintained for the duration of the experiments. Moreover, in all three plant species, ISR was induced by preparations of the bacterial lipopolysaccharide $(4,12,13)$, ruling out any protective effects due to bacterial metabolism.

Both Kloepper and coworkers and we have shown that similar strains of PGPR protect various plant species against diseases caused by different types of pathogens, and in doing so, both groups have independently validated the other's results. PGPR-mediated ISR is an important mechanism of biological disease control, and it can

Corresponding author: L. C. van Loon

E-mail address: k.vanloon@boev.biol.ruu.nl

Publication no. P-1997-0113-010

(C) 1997 The American Phytopathological Society be as effective as pathogen-induced systemic acquired resistance $(1,2)$. Both Leeman et al. (5) and Wei et al. (15) have shown that PGPR are effective in reducing diseases under field conditions. This makes it even more important to further characterize the physiological, biochemical, and molecular mechanisms involved to make optimal use of ISR in plant protection.

\section{LITERATURE CITED}

1. Hoffland, E., Hakulinen, J., and Van Pelt, J. A. 1996. Comparison of systemic resistance induced by avirulent and nonpathogenic Pseudomonas species. Phytopathology 86:757-762.

2. Kloepper, J. W., Tuzun, S., Liu, L., and Wei, G. 1993. Plant growth-promoting rhizobacteria as inducers of systemic disease resistance. Pages 156-165 in: Pest Management: Biologically Based Technologies. R. D. Lumsden and J. L. Vaughn, eds. American Chemical Society Books, Washington, DC.

3. Leeman, M., Van Pelt, J. A., Den Ouden, F. M., Heinsbroek, M., Bakker, P. A. H. M., and Schippers, B. 1995. Induction of systemic resistance by Pseudomonas fluorescens in radish cultivars differing in susceptibility to Fusarium wilt, using a novel bioassay. Eur. J. Plant Pathol. 101:655-664.

4. Leeman, M., Van Pelt, J. A., Den Ouden, F. M., Heinsbroek, M., Bakker, P. A. H. M., and Schippers, B. 1995. Induction of systemic resistance against Fusarium wilt of radish by lipopolysaccharides of Pseudomonas fluorescens. Phytopathology 85:1021-1027.

5. Leeman, M., Van Pelt, J. A., Hendrickx, M. J., Scheffer, R. J., Bakker, P. A. H. M., and Schippers, B. 1995. Biocontrol of Fusarium wilt of radish in commercial greenhouse trials by seed treatment with Pseudomonas fluorescens WCS374. Phytopathology 85:1301-1305.

6. Liu, L., Kloepper, J. W., and Tuzun, S. 1992. Induction of systemic resistance against cucumber mosaic virus by seed inoculation with select rhizobacteria strains. (Abstr.) Phytopathology 82:1108-1109.

7. Liu, L., Kloepper, J. W., and Tuzun, S. 1995. Induction of systemic resistance in cucumber against Fusarium wilt by plant growth-promoting rhizobacteria. Phytopathology 85:695-698.

8. Liu, L., Kloepper, J. W., and Tuzun, S. 1995. Induction of systemic resistance in cucumber against angular leaf spot by plant growth-promoting rhizobacteria. Phytopathology 85:843-847.

9. Liu, L., Kloepper, J. W., and Tuzun, S. 1995. Induction of systemic resistance in cucumber by plant growth-promoting rhizobacteria: Duration of protection and effect of host resistance on protection and root colonization. Phytopathology 85:1064-1068.

10. Pieterse, C. M. J., Van Wees, S. C. M., Hoffland, E., Van Pelt, J. A., and Van Loon, L. C. 1996. Systemic resistance in Arabidopsis induced by biocontrol bacteria is independent of salicylic acid accumulation and pathogenesis-related gene expression. Plant Cell 8:1225-1237.

11. Van Peer, R., Niemann, G. J., and Schippers, B. 1991. Induced resistance and phytoalexin accumulation in biological control of Fusarium wilt of carnation by Pseudomonas sp. strain WCS417r. Phytopathology 81:728-734.

12. Van Peer, R., and Schippers, B. 1992. Lipopolysaccharides of plant growthpromoting Pseudomonas sp. strain WCS417r induce resistance in carnation to Fusarium wilt. Neth. J. Plant Pathol. 98:129-139.

13. Van Wees, S. C. M., Pieterse, C. M. J., Van 't Westende, Y. A. M., and Van Loon, L. C. 1996. Arabidopsis as a model to study systemic resistance induced by biocontrol bacteria. Page Nr. D-17 in: Abstr. 8th Int. Congr. Mol. Plant-Microbe Interact. University of Tennessee, Knoxville.

14. Wei, G., Kloepper, J. W., and Tuzun, S. 1991. Induction of systemic resistance of cucumber to Colletotrichum orbiculare by select strains of plant growth-promoting rhizobacteria. Phytopathology 81:1508-1512.

15. Wei, G., Kloepper, J. W., and Tuzun, S. 1996. Induced systemic resistance to cucumber diseases and increased plant growth by plant growth-promoting rhizobacteria under field conditions. Phytopathology 86:221-224. 